\title{
Emosi Moral dan Empati pada Pelaku Perundungan-siber
}

\author{
Neila Ramdhani ${ }^{1}$ \\ Fakultas Psikologi Universitas Gadjah Mada
}

\begin{abstract}
The variety and frequency of behaviors including the category of cyber-bullying have been increasing lately. Every Internet user can easily publish their emotions and thoughts in the Internet, including their negative emotions intended to harm other people. This research tested the effects of moral emotions in the relationship of empathy and cyber-bullying behaviors. The moral emotions tested were shame, guilt, authentic pride, and hubristic pride while the empathy contained cognition and affection. The data analyzed in this study were collected from 382 subjects consisting of 174 high school students and 208 university students. Among them there were 103 female students and the rest were male ones. All the partisipants answered the questions asked in the Moral Emotion Scale, Empathy Scale and Cyber-Bullying Scale. Based on the results of a regression analysis, this study revealed that it was the cognitive dimension only that contributed to cyber-bullying. In addition, although all moral emotions contributed significantly to cyberbullying, guilt was the only dimension that strengthened the rople of empathy in cyber-bullying.
\end{abstract}

Keywords: cyber-bullying, moral emotions, empathy, shame, guilt, hubristic-pride, authentic-pride

\begin{abstract}
Abstrak. Ragam dan frekuensi tindakan yang masuk dalam kategori perundungan-siber semakin meningkat akhir-akhir ini. Setiap pengguna internet dapat dengan mudah mempublikasikan emosi dan pikirannya di internet, termasuk di dalamnya emosi negatif yang ditujukan untuk menyakiti orang lain. Penelitian ini menguji pengaruh emosi moral di dalam hubungan empati dengan perilaku perundungan-siber. Emosi moral yang diuji adalah malu, bersalah, kebanggaan hubristic dan kebanggaan autentik sedangkan empati meliputi kognitif dan afektif. Data yang dianalisis dalam penelitian ini berasal dari 382 orang, 174 siswa SLTA dan 208 mahasiswa, 103 perempuan sedangkan sisanya laki-laki. Semua partisipan menjawab pertanyaan Skala Emosi Moral, Skala Empati, dan Skala Perundungan-siber. Setelah dilakukan analisis regresi diperoleh hasil bahwa hanya dimensi empati kognitif yang berperan terhadap perundungan-siber. Penelitian ini juga memperlihatkan bahwa walaupun semua dimensi emosi moral memberikan sumbangan signifikan terhadap perundungan-siber namun hanya dimensi rasa berdosa saja yang memperkuat peran empati terhadap perundungan-siber.
\end{abstract}

Kata kunci: perundungan-siber, emosi-moral, empati, malu, bersalah, bangga autentik, hubristic

'Ibarat dua sisi mata uang', internet memberikan manfaat yang besar bagi kehidupan manusia sekaligus juga dampak negatif yang dapat dialami oleh penggunanya (Turkle, 2005). Dari sisi positif, internet telah memudahkan penggunanya dalam bekerja, menjalin

\footnotetext{
${ }^{1}$ Korespondensi mengenai artikel ini dapat dilakukan melalui: neila_psi@ugm.ac.id
}

hubungan interpersonal, berbisnis, bahkan sebagai gudang pengetahuan. Pada waktu lalu, seseorang harus temu muka atau setidaknya menggunakan teknologi sinkronous untuk dapat bercengkerama. Internet telah mengubah kehidupan sosial karena keharusan bertemu muka itu sudah tidak diperlukan lagi. Chatting, email, sms, blogging, dan media sosial telah 
menjadi media yang memudahkan penggunanya untuk dapat berkomunikasi. Pekerjaan sudah menjadi lebih mudah dilakukan dengan fasilitas internet.

Sebaliknya, sisi negatif yang saat ini semakin banyak dikeluhkan adalah pemanfaatan internet membuat orang enggan untuk bertemu muka. Dalam batas tertentu kondisi ini dapat dipahami namun permasalahan menjadi serius pada saat pengguna internet seakan menikmati kesendirian karena kebutuhan manusia untuk berinteraksi telah dapat dipenuhi oleh internet. Keadaan menjadi memburuk bila internet dimanfaatkan oleh oknum yang tidak bertanggung jawab baik dalam penipuan, memfitnah, mengancam dan berbagai perilaku merugikan yang dimasukkan ke dalam kategori perundungan-siber.

Perundungan-siber adalah istilah yang dikenalkan di dalam tulisan ini sebagai terjemahan ke dalam bahasa Indonesia dari cyberbullying. Patchin dan Hinduja (2006) menyebutkan bahwa perundungan-siber adalah bentuk agresi yang dilakukan melalui media sosial dan teknologi informasi dan komunikasi (TIK). Serupa halnya dengan perundungan (berbagai tulisan menyebutnya dengan traditional bullying), perundungan-siber dapat berisi ancaman dan menyudutkan, dilakukan secara berulang, dengan maksud membuat target merasa tidak nyaman (Berne, Frisen, Schultze-Krumbolz, Scheithauer, Naruskov, Luik, Katzer, Erentaite, \& Zukauskiene, 2013; Wong-Lo \& Bullock, 2014). Perbedaan yang menonjol antara keduanya adalah ketiadaan perbedaan posisi atau kekuatan (Hoff \& Mitchell, 2009) antara pelaku dan target karena perundungan-siber dapat dilakukan dengan mudah bahkan dari ruangan yang sangat pribadi.
Meningkatnya jumlah pelaku perundungan-siber, selanjutnya disebut dengan perundung-siber, menjadi perhatian serius dari berbagai pihak. Dari perspektif psikologi-siber, peluang untuk berada di ruang pribadi memposisikan pengguna internet ke dalam kondisi tidak dikenali (anonymous), karena orang lain tidak ada yang mengetahui apa yang sedang ia lakukan di balik monitornya (Suller, 1996). Kemudahan dalam menggunakan teknologi internet yang dapat diakses ' $k$ lik' hanya dengan piranti kecil di dalam genggaman membawa pengguna internet ke dalam situasi bebas tanpa terikat akan aturan moral (online dis-inhibition effect). Kondisi lain yang dapat dialami oleh pengguna internet adalah kebebasan yang menyenangkan karena semua hal dapat dilakukannya dengan satu klik sehingga mengundang keisengan untuk bermain (dissociative imagination) bahkan tanpa berpikir tentang dampak yang dialami oleh korban perundungan-siber.

Di dalam kehidupan sosial, sebetulnya perilaku mengganggu orang lain termasuk di dalamnya berbohong, menyontek, menyakiti orang lain, dan perundungan baik tradisional maupun siber, dimasukkan ke dalam kategori perilaku yang tidak sesuai dengan nilainilai moral kehidupan antar manusia. Namun demikian, hingga saat ini masih banyak dilakukan bahkan berita perundungan-siber cenderung meningkat sehingga perlu kajian lebih mendalam tentang hal ini.

Memahami meningkatnya perundungan-siber dari perspektif psikologisiber (cyberpsychology) lebih cenderung membahas kondisi psikologis individu pada saat terlibat di dalam penggunaan TIK. Tulisan ini memberikan porsi kepada aspek kepribadian yang memberi sumbangan pada saat individu mem- 
bangun hubungan interpersonal yaitu empati. Aspek lain yang juga diperhitungkan adalah emosi moral yang diduga memengaruhi perilaku individu mengingat perundungan-siber terkait konsekuensi perilakunya bagi orang lain.

\section{Empati dan Perundungan-siber}

Empati merupakan salah satu aspek kognisi sosial yang memainkan peran penting pada saat individu merespons emosi orang lain dalam rangka membangun hubungan dengan orang lain (Spreng, McKinnon, Mar, \& Levine, 2009). Empati mewujud pada saat seseorang berkomunikasi dalam rangka membangun hubungan interpersonal dimana individu menyampaikan pesan kepada orang lain dan sekaligus juga menerima pesan dari orang lain dengan siapa ia berkomunikasi. Pesan yang dikirim dan diterima di dalam berkomunikasi memuat pesan verbal maupun non-verbal sehingga di dalam proses komunikasi terjadi aktivitas memahami isi pesan verbal (baik lisan maupun tertulis) dan mengamati isyarat non verbal. Keharmonisan hubungan interpersonal yang terjalin sangat dipengaruhi oleh empati dari pelaku komunikasi yang terlibat di dalam hubungan interpersonal tersebut.

Empati merupakan satu ciri sifat yang relatif stabil dari kepribadian individu, didefinisikan sebagai kemampuan individu untuk dapat ikut merasakan emosi yang dialami orang lain (Hoffman, 2001). Misalnya, seseorang akan ikut merasakan kesedihan ketika menyaksikan rekannya ditimpa kemalangan. Empati memfasilitasi terjadinya proses berbagi dan mengkomunikasikan rasa yang dialami oleh seseorang, sehingga terjadi proses asimilasi terhadap rasa sedih yang dialami tersebut menjadi bagian dari perasaannya (Decety \& Jackson, 2006).

Kajian lain tentang empati dilakukan oleh Blair (2005) yang memandang empati dari sisi neurosains. Walaupun Blair mengemukakan bahwa empati ada tiga, yaitu empati motorik, empati kognitif, dan empati emosional namun tulisan ini hanya akan membahas empati sebagai konsep multidimensi yang lebih relevan dengan moral, yaitu afektif dan kognitif (Davis, 1980, 1983; Eisenberg \& Fabes, 1990; Miklikowska, Duriez, \& Soenens, 2011). Komponen afektif serupa dengan yang dikemukakan oleh Hoffman (1981), sering juga disebut dengan perhatian yang empatik atau simpati atas kondisi internal seseorang. Perhatian yang diberikan atas dasar keprihatinan seringkali disertai dengan adanya rasa cemas terhadap kondisi diri sendiri dan orang lain ini menjadi pemotivasi bagi individu untuk mengurangi penderitaan orang lain.

Empati kognitif terjadi bila individu merepresentasikan situasi internal mental dari orang lain. Definisi ini agak mirip dengan Theory of Mind (ToM) dimana individu memasukkan sudut pandang atau perspektif orang lain ke dalam dirinya dan menggunakannya untuk memahami situasi, kondisi, dan jalan pikiran orang lain (Adler \& Proctor, 2014). Banyak artikel yang menggunakan perumpamaan 'meletakkan kakinya ke dalam sepatu orang lain' untuk mempermudah dalam memahami empati. Komponen kognitif dari empati dapat dilihat pada saat individu mengambil dan menggunakan perspektif orang lain tentang kondisi, situasi, dan pola pikir yang memposisikan orang tersebut dalam keadaan tertentu (Hemmerdinger, Stoddart, \& Lilford, 2007), termasuk ketika individu membaca novel, menonton film, dan lain-lain. 
Keterlibatan komponen kognitif dan afektif dalam memahami empati ini memengaruhi perilaku individu untuk dapat memenuhi kebutuhan orang lain (Batson, Eklund, Chermok, Hoyt, \& Ortiz, 2007). Empati memfasilitasi individu untuk dapat lebih memahami orang lain, menurut Endresen dan Olweus (2001) rendahnya empati berkorelasi dengan perilaku agresif, termasuk di dalamnya perundungan (bullying).

Keterkaitan antara empati dengan perundungan-siber secara umum sudah dilaporkan oleh Steffgen, König, Pfetsch, dan Melzer (2011) melalui meta-analisis terhadap 2.070 mahasiswa yang memperlihatkan bahwa perundung-siber memiliki empati yang rendah. Hubungan antara variabel empati dengan perundungan-siber ini diperkuat oleh temuan Del Rey, Lazuras, Casas, Barkoukis, Ortega-Ruiz, dan Tsorbatzoudis (2016). Dengan demikian dugaan adanya peran empati dalam menentukan perundungansiber cukup beralasan.

\section{Emosi Moral dan Perundungan-siber}

Hubungan antara emosi dengan perilaku moral sudah banyak dibahas dalam beberapa artikel (Blasi, 1999) dapat dijelaskan dengan traits model maupun arousal model. Pada traits model, emosi terkait erat dan menjadi penghubung antara variabel pemotivasi perilaku lainnya seperti misalnya tujuan, keyakinan, dan dorongan dengan lingkungan. Dalam hal ini, emosi akan menjadi pemotivasi bagi pemenuhan kebutuhan atau pencapaian tujuan apabila pada saat itu lingkungan dipandang memungkinkan. Agak berbeda dengan arrousal model yang lebih memposisikan emosi sebagai suatu gairah atau reaksi yang muncul pada diri individu karena ada ketegangan. Pada model kedua ini, emosi berfungsi memo- tivasi individu untuk bertindak agar ketegangan menurun.

Emosi moral, biasanya disebut juga self-conscious emotions, yaitu emosi yang dihasilkan dari evaluasi seseorang terhadap dirinya dan perilakunya dibandingkan dengan standar moral dan tata nilai (Tangney, Stuewig, \& Mashek, 2007; Tangney \& Tracy, 2011). Tata nilai ini dapat berasal dari penilaian pribadi maupun mengadopsi dari orang-orang penting di dalam hidup individu. Emosi moral adalah emosi yang muncul pada saat individu merespons suatu pelanggaran moral, atau memotivasi perilaku moral (Haidt, 2003) yaitu perilaku yang dikaitkan dengan standar, peraturan, tujuan. Secara naluriah sebetulnya individu ingin memenuhi standar moral, yang merepresentasikan pengetahuan dan nilainilai yang diinternalisasi atau konvensi yang diyakini individu. Perilaku yang membawa konsekuensi negatif terhadap kesejahteraan individu dipandang sebagai tidak memenuhi standar moral, seperti misalnya kekerasan, kriminal, berbohong, mencuri, dan mencopet. Perundungansiber merupakan salah satu perilaku yang secara universal tidak memenuhi standar moral walaupun perundung-siber makin hari makin meningkat.

Tangney, et al. (2007) mengemukakan bahwa emosi moral adalah emosi yang muncul pada saat seseorang mengevaluasi perilaku dan cara berpikirnya berdasarkan kepada standar moral. Emosi moral mengantarai intensi dan perilaku terkait moral. Setidaknya ada tiga emosi moral utama yaitu shame, guilt, dan embarrassment (Haidt, 2003), yang selanjutnya dapat dikategorikan emosi moral negatif karena munculnya menyertai perilaku yang di bawah standar, aturan, dan tujuan. Tangney, et al. (2007) menambahkan emosi moral lainnya yang 
dikategorikan positif yaitu pride. Tulisan ini hanya akan membahas tentang shame, guilt, dan pride saja. Embarrassment tidak akan diungkap dengan mempertimbangkan hasil penelitian yang dilakukan bahwa di Indonesia shame dan embarrassment dimaknai dengan satu kata yang sama yaitu malu (Fessler, 1999).

Shame (untuk selanjutnya akan diterjemahkan malu) dialami seseorang apabila ia merasa mengalami atau melakukan perbuatan yang tidak sesuai atau tidak memenuhi standar, tidak mematuhi aturan, dan bertujuan tidak baik. Malu dikategorikan ke dalam emosi moral yang berorientasi ke dalam diri sendiri (Casey, 2014) sehingga pada saat merasa malu, individu cenderung menyalahkan dirinya sendiri (Tangney, Malouf, Stuewig, \& Mashek, 2011), memandang dirinya rendah dan tidak kompeten (Brown, 2010). Secara fisik, perasaan malu ini membuat individu merasa 'kecil' (Tangney, et al., 2007), terperangkap, tidak berdaya, sehingga ia merasa tidak layak bertemu dengan orang banyak karena ia merasa semua orang sedang memandanginya (Robinaugh \& McNally, 2010).

Serupa dengan malu, rasa bersalah (terjemahan dari guilt) adalah emosi moral yang juga dirasakan pada saat individu melanggar standar, tidak mematuhi aturan, dan tujuan yang tidak baik (Tangney \& Tracy, 2011). Berbeda dengan malu yang dampaknya dirasakan mendalam oleh diri individu sendiri, perasaan bersalah diarahkan kepada perilaku spesifik yang tidak tepat dilakukan individu yang akibatnya dirasakan oleh orang lain (Tangney, et al., 2007). Oleh karena lebih fokus kepada perilaku yang terlihat maka rasa bersalah dikatakan lebih konstruktif sebab fokusnya pada perilaku sehingga lebih mudah mengoreksi perilakunya (Tangney, Stuewig, \& Hafez, 2011; Tangney, et al., 2011).

Bila malu dan bersalah disebabkan karena perilaku individu di bawah atau melanggar standar moral, berbeda dengan pride yang dikategorikan ke dalam emosi moral positif, dirasakan ketika individu merasa berhasil memenuhi bahkan melebihi standar, aturan, dan tujuan yang ia tetapkan. Pada awalnya konsep pride ini dipandang sebagai mono dimensi (Weiner, 1985) berkorelasi positif dengan perilaku prososial dan berkorelasi negatif dengan agresivitas. Penelitian yang dilakukan Tracy dan Robins (2007) memperlihatkan bahwa pride dapat dipisahkan menjadi dua, yaitu authentic pride berkorelasi dengan perilaku prososial sedangkan hubristic pride berkorelasi dengan perilaku agresif.

Kamus Psikologi mencantumkan hubristic berasal dari kata hubris yang bermakna arogan, kebanggaan yang terlalu kuat (APA, 2013). Hubristic pride atau disebut selanjutnya dengan kebanggaan hubristic dimiliki individu karena memenuhi bahkan melebihi standar memiliki potensi atau talenta. Kebanggaan hubristic ini dikaitkan dengan potensi yang telah dimiliki individu dan dominansi (Holbrook, Piazza, \& Fessler, 2014), sehingga mendorong individu untuk memperlihatkannya kepada orang lain sehingga pada beberapa artikel dikemukakan mempunyai kecenderungan destruktif (Casey, 2014; Tracy \& Robins, 2007).

Definisi kebanggaan hubristic ini berbeda dengan kebanggaan otentik dimana individu merasa puas hati pada saat berhasil memenuhi standar, aturan, dan tujuan yang ia tetapkan setelah bekerja dan berusaha keras. Fokus dari kebanggaan otentik adalah usaha yang dilakukan individu bukan kepada kelebihan atau potensi yang ia miliki. Kata 
kunci lain yang dikaitkan dengan kebanggaan otentik adalah prestise yang diperoleh setelah berusaha, bukan perasaan dominan karena telah berhasil (Tracy, Shariff, \& Cheng, 2010; Holbrook, et al., 2014).

\section{Empati, Emosi Moral, dan Perundungan-siber}

Hipotesis penelitian ini dibangun dengan memperhitungkan peran empati kognitif terhadap perundungan-siber. Individu yang memiliki empati, baik kognitif maupun afektif yang tinggi maka kecenderungan melakukan perundungansiber akan rendah, apalagi bila mereka dipengaruhi oleh emosi moral positif. Sebaliknya, apabila individu dikuasai oleh emosi moral negatif maka peran empati akan menurun.

Kemampuan menggunakan atau mengambil perspektif orang lain menimbulkan pemahaman bagi individu mengenai akibat dari suatu perilaku. Demikian pula halnya pada empati afektif yang ditandai dengan adanya kemampuan untuk ikut merasakan emosi dari orangorang yang diamatinya. Bila perundungan-siber dipandang sebagai suatu tindakan yang mengakibatkan perasaan tidak nyaman bagi korban maka individu dengan empati kognitif maupun afektif tidak akan melakukan perundungan-siber.

Hasil evaluasi diri terhadap dampak emosional dari suatu perilaku, baik positif maupun negatif, juga memberi pengaruh terhadap perilaku moral seorang individu. Beberapa penelitian melaporkan adanya kaitan antara evaluasi diri ini dengan perilaku moral. Apabila empati dipandang sebagai variabel independen bagi perundungan-siber, bagaimana posisi dari variabel emosi moral? Apakah emosi moral juga merupakan prediktor atau moderator bagi perundungan-siber?

\section{Hipotesis}

(1) Empati merupakan prediktor dari perundungan-siber. Dengan mengacu kepada konsep multidimensi dari empati, hipotesis ini terdiri dari dua yaitu: (1.a.) empati kognitif berpengaruh negatif terhadap kecenderungan melakukan perundungan-siber, (1.b.) empati afektif berpengaruh negatif terhadap kecenderungan melakukan perundungan-siber. (2) Emosi moral negatif merupakan prediktor dari perundungan-siber. Hipotesis ini terdiri dari dua, yaitu: (2.a.) malu berpengaruh positif terhadap kecenderungan melakukan perundungan-siber, (2.b.) rasa bersalah berpengaruh positif terhadap kecenderungan melakukan perundungansiber. (3) Emosi moral positif merupakan prediktor dari perundungan-siber. Hipotesis ini terdiri dari dua, yaitu: (3.a) rasa bangga hubristic berpengaruh negatif terhadap kecenderungan melakukan perundungan-siber, (3.b) rasa bangga autentik berpengaruh negatif terhadap kecenderungan melakukan perundungansiber, dan (4) Emosi moral, baik negatif maupun positif, memoderasi hubungan empati dengan kecenderungan melakukan perundungan-siber.

\section{Metode}

\section{Partisipan penelitian}

Remaja bejumlah 382 orang, 174 (45,5\%) siswa SLTA sedangkan 208 (54,5\%) mahasiswa, 103 (27\%) perempuan sedangkan sisanya laki-laki. Mereka sudah menyatakan kesediaan menjawab pertanyaan yang ada pada skala dengan sukarela. Prosedur pengambilan data yang dilakukan sudah memenuhi standar yang ditetapkan oleh Komite Etika Penelitian Fakultas Psikologi UGM. 


\section{Pengukuran}

Pengumpulan data dalam penelitian ini dilakukan dengan menggunakan tiga skala yang mengungkap ketiga variabel. Data tentang pengalaman melakukan perilaku perundungan-siber diungkap dengan 24 aitem Skala Perundungan-siber (SPS). Skala ini memuat 24 aktivitas yang masuk ke dalam kategori perundungansiber dengan lima alternatif jawaban mulai dari tidak pernah hingga selalu. Contoh aitem dari SPS adalah 'mengancam teman melalui media sosial' dan 'membuat lelucon konyol tentang teman di media sosial'. SPS ini sudah diuji cukup reliabel dengan $\alpha=0,82$.

Data empati diungkap dengan Skala Empati (SE) yang terdiri dari 20 aitem yang diambil dari 28 aitem (IRI) Interpersonal Reactivity Index (Davis, 1983). Delapan aitem IRI tidak digunakan dengan mempertimbangkan kesesuaian pernyataan dengan karakteristik partisipan penelitian. Skala Empati ini terdiri dari dua dimensi, yaitu kognitif dan afektif. Dimensi kognitif dari empati meliputi pengambilan perspektif orang lain (perspective taking) yaitu reaksi spontan seseorang menggunakan sudut pandang orang yang diamatinya, dan fantasi yaitu kecenderungan individu untuk menjelma-kan dirinya ke dalam tokoh atau karakter yang ada di dalam sebuah novel atau film. Contoh aitem dimensi kognitif dari empati adalah 'Saya terkadang sulit untuk memahami pandangan dari sisi orang lain' dan 'Saya merasa sangat terlibat dengan perasaan karakter yang ada di dalam sebuah novel'. Dimensi empati afektif terdiri dari keprihatinan empatik (empathic concern) yaitu kondisi dimana seseorang ikut merasakan suasana emosi yang dialami seseorang yang ditimpa kemalangan, dan stres personal yaitu perasaan cemas dan tegang yang dialami individu. Contoh aitem untuk mengungkap dimensi empati afektif adalah 'Saat saya melihat seseorang dimanfaatkan, saya merasa ingin melindunginya' dan 'Pada saat mendesak, saya merasa khawatir dan tidak tenang'. Skala Empati sudah diuji cobakan dengan reliabilitas $\alpha=0,79$.

Emosi moral diukur dengan Skala Emosi Moral (SEM) yang merupakan terjemahan dari Test of Self-Conscious Affect for Adolescents, The TOSCA-A yang disusun dan dikembangkan oleh Tangney (Tracy, Robins, \& Tangney, 2007). Skala Emosi Moral (SEM) ini terdiri dari 10 skenario negatif dan lima skenario positif, yang diikuti dengan pilihan respons individu mengungkap emosi-emosi malu, rasa bersalah, dan bangga.

Proses penerjemahan Skala Empati dan Skala Emosi Moral dilakukan dengan prosedur penerjemahan secara bahasa maupun penyesuaian budaya yang dikemukakan oleh Brislin (1970). Khusus untuk SEM penerjemahan ke dalam bahasa Indonesia dilakukan oleh Damanik, Widodo, Sutandi, Mayawati, dan Widyatmoko (2013).

\section{H a s i 1}

Data yang terkumpul dari penelitian ini memperlihatkan bahwa laki-laki lebih banyak terlibat dalam perundungan-siber $(M=10,5 ; S D=8)$ dibandingkan dengan perempuan $(M=7,13 ; S D=5,19)$, perbedaan ini terbukti signifikan $(F=$ 34,43; $p<0,01)$. Hasil sebaliknya diperoleh bahwa tingkat pendidikan tidak membedakan kecenderungan melakukan perundungan-siber ini.

\section{Empati dan Perundungan-siber}

Sebagaimana didefinisikan oleh Davis (1980) bahwa empati merupakan konsep 
multidimensi yang melibatkan dimensi kognitif dan afektif. Dalam penelitian ini, kedua dimensi dianalisis secara terpisah, diperoleh hasil bahwa dimensi empati kognitif berkorelasi dengan perundungansiber sebesar $r=0,11(p<0,05)$ sedangkan dimensi empati afektif berkorelasi sebesar $r=0,08(p>0,05)$ dengan kecenderungan melakukan perundungan-siber (Tabel 1). Dengan hasil ini, hipotesis (1.a) terbukti sedangkan (1.b) tidak diterima sehingga empati afektif tidak akan diikutkan untuk pengujian variabel moderator.

\section{Emosi moral dan Perundungan-siber}

Keempat dimensi emosi moral, yaitu malu, rasa bersalah, rasa bangga hubristic, dan rasa bangga autentik merupakan preditor bagi perundungan-siber (lihat Tabel 2). Rasa bersalah adalah dimensi emosi moral yang paling besar perannya dan berpengaruh positif terhadap perundungan-siber. Hasil ini mendukung hipotesis 2.b. bahwa semakin merasa bersalah maka kecenderungan individu melakukan perundungan-siber akan semakin tinggi. Emosi moral lain yang juga berpengaruh kuat adalah malu. Berbeda dengan rasa bersalah yang berpengaruh positif, hasil analisis data tidak sesuai dengan hipotesis 2.a. karena malu berpengaruh negatif terhadap perundungan-siber, sehingga dapat dikatakan bahwa semakin tinggi emosi malu seorang individu makin kecil kemungkinan terlibat dalam perundungan-siber.

Tabel 2 juga memperlihatkan bahwa rasa bangga, baik hubristic maupun autentik, juga berpengaruh negatif terhadap perundungan-siber. Hasil analisis data penelitian ini mendukung hipotesis 3.a. dan 3.b. bahwa individu yang merasa bangga, baik disebabkan oleh keistimewaan kompetensi yang dimilikinya maupun disebabkan oleh kerja kerasnya sehingga mencapai prestasi yang diinginkan, cenderung kurang terlibat di dalam perundungan-siber.

Apakah emosi moral memoderasi hubungan empati kognitif dan perundungan-siber?

Hasil analisis terhadap peran kedua variabel bebas, yaitu empati kognitif dan emosi moral terhadap perundungan-siber memberikan gambaran bahwa perundungan-siber secara signifikan dipengaruhi oleh empati kognitif maupun dimensi dari emosi moral.

Tabel 1

Analisis Regresi Peran Empati Kognitif dan Afektif terhadap Perundungan-siber

\begin{tabular}{|c|c|c|c|c|c|}
\hline \multirow{2}{*}{ Dimensi } & \multicolumn{2}{|c|}{ Unstandardized } & \multirow{2}{*}{$\begin{array}{c}\text { Standardized } \\
\text { Beta }\end{array}$} & \multirow[t]{2}{*}{$t$} & \multirow[t]{2}{*}{$p$} \\
\hline & $\mathrm{B}$ & Std. Eror & & & \\
\hline Empati Kognitif & 0,15 & 0,7 & 0,11 & 2,19 & $<0,01$ \\
\hline Empati Afektif & 0,11 & 0,7 & 0,08 & 1,52 & $>0,05$ \\
\hline
\end{tabular}

Tabel 2

Analisis Regresi Variabel Emosi Moral terhadap Perundungan-siber

\begin{tabular}{|c|c|c|c|c|c|}
\hline \multirow{2}{*}{ Dimensi } & \multicolumn{2}{|c|}{ Unstandardized } & \multirow{2}{*}{$\begin{array}{c}\text { Standardized } \\
\text { Beta }\end{array}$} & \multirow[t]{2}{*}{$t$} & \multirow[t]{2}{*}{$p$} \\
\hline & $B$ & Std. Eror & & & \\
\hline Malu & $-0,12$ & 0,04 & $-0,14$ & $-2,76$ & $<0,01$ \\
\hline Rasa Bersalah & 0,24 & 0,05 & 0,24 & 4,91 & $<0,01$ \\
\hline Bangga Hubristic & $-0,27$ & 0,11 & $-0,12$ & $-2,43$ & $<0,05$ \\
\hline Bangga Autentik & $-0,23$ & 0,10 & $-0,11$ & $-2,12$ & $<0,05$ \\
\hline
\end{tabular}


Pengujian berikutnya adalah untuk mengetahui peran masing-masing dimensi emosi moral sebagai variabel moderator bagi hubungan empati kognitif dengan perundungan-siber. Uji moderator ini dilakukan dengan regresi berjenjang terhadap perundungan-siber, yang dilakukan bertahap yaitu: (1) variabel empati menghasilkan Model 1, (2) variabel empati dan masing-masing dimensi emosi moral yang menghasilkan Model 2, dan (3) variabel empati, emosi moral, dan moderator. Hasil ringkasan perhitungan terdapat pada Tabel 3, bahwa di antara keempat dimensi emosi moral, hanya rasa bersalah saja yang signifikan memoderasi hubungan empati kognitif dengan perundungan-siber. Sedangkan, tiga dimensi emosi moral lainnya memberikan sumbangan lebih baik pada saat diperlakukan sebagai variabel independen bersama-sama dengan empati kognitif.
Tabel 4 dipergunakan untuk menyusun persamaan regresi untuk dimensi rasa bersalah, yaitu:

$$
Y=8,23-0,29 X 1-0,04 X 2+0,02 X 1 X 2
$$

dimana: $Y=$ Perundungan-siber

X1 = Empati Kognitif

$\mathrm{X} 2=$ Rasa bersalah

\section{Diskusi}

Diskusi tentang hubungan antara emosi moral dan perundungan-siber ini dimulai dengan menjawab pertanyaan tentang prediktor mana yang lebih kuat pengaruhnya terhadap perundungansiber. Apakah jenis kelamin atau tingkat pendidikan? Pertanyaan berikut juga ingin dijawab di dalam tulisan ini, mengapa rasa berdosa menjadi prediktor terkuat dari perundungan-siber?

Tabel 3

Ringkasan Analisis Variabel Emosi Moral sebagai Moderator

\begin{tabular}{lcccccc}
\hline \multirow{2}{*}{ Dimensi } & \multicolumn{2}{c}{ Model 1 } & \multicolumn{2}{c}{ Model 2 } & \multicolumn{2}{c}{ Model 3 } \\
\cline { 2 - 7 } M Square & $F$ & R Square & $F$ & R Square & $F$ \\
\hline Balu & 0,01 & $4,78^{*}$ & 0,04 & $10,76^{* *}$ & 0,04 & 0,76 \\
Hubristic & 0,01 & $4,76^{*}$ & 0,06 & $19,18^{* *}$ & 0,07 & $4,26^{*}$ \\
Autentik & 0,01 & $4,78^{*}$ & 0,03 & $7,98^{* *}$ & 0,03 & 0,03 \\
\hline
\end{tabular}

Keterangan: $\left.\left.{ }^{*}\right)=p<0,05 ;{ }^{* *}\right)=p<0.01$

Tabel 4

Ringkasan Hasil Analisis Regresi Berjenjang

\begin{tabular}{|c|c|c|c|c|c|c|}
\hline & \multirow[t]{2}{*}{ Model } & \multicolumn{2}{|c|}{$\begin{array}{l}\text { Unstandardized } \\
\text { Coefficients }\end{array}$} & \multirow{2}{*}{$\begin{array}{c}\text { Standardized } \\
\text { Coefficients }\end{array}$} & \multirow[t]{2}{*}{$t$} & \multirow[t]{2}{*}{ Sig. } \\
\hline & & $B$ & Std. Error & & & \\
\hline \multirow[t]{2}{*}{1} & (Constant) & 6,39 & 1,04 & & 6,17 & 0,00 \\
\hline & Kognitif_E & 0,15 & 0,07 & 0,11 & 2,19 & 0,03 \\
\hline \multirow[t]{3}{*}{2} & (Constant) & 3,92 & 1,16 & & 3,38 & 0,00 \\
\hline & Kognitif_E & 0,03 & 0,07 & 0,02 & 0,41 & 0,68 \\
\hline & Guilt & 0,23 & 0,05 & 0,24 & 4,38 & 0,00 \\
\hline \multirow[t]{4}{*}{3} & (Constant) & 8,23 & 2,39 & & 3,45 & 0,00 \\
\hline & Kognitif_E & $-0,29$ & 0,17 & $-0,21$ & $-1,69$ & 0,09 \\
\hline & Guilt & $-0,04$ & 0,14 & $-0,04$ & $-0,30$ & 0,76 \\
\hline & Mod_Guilt & 0.02 & 0,01 & 0,44 & 2,06 & 0,04 \\
\hline
\end{tabular}


Sebagaimana dilaporkan oleh Suparli dan Ramdhani (2004), penelitian ini juga memperlihatkan bahwa laki-laki mempunyai kecenderungan melakukan perundungan-siber lebih tinggi dibandingkan dengan perempuan. Temuan lain yang diperoleh dari penelitian ini bahwa tingkat pendidikan, apakah sekolah menengah atau universitas tidak membedakan kecenderungan melakukan perundungsiber. Nampaknya selisih usia dan tahap perkembangan yang tidak begitu berbeda sehingga semua kategori berada di dalam kelompok yang sama, yaitu sedang. Hasil ini juga mendukung temuan Suparli dan Ramdhani tersebut.

Empati didefinisikan sebagai ciri kepribadian yang dimiliki oleh individu yang mampu memposisikan dirinya merasakan apa yang dirasakan orang lain. Dari dua dimensi empati, hanya empati kognitif yang berperan signifikan terhadap perundungan-siber ini. Secara kognitif, individu yang mampu mengenali dan menggunakan perspektif orang lain berperan dalam menurunkan tingkat kecenderungan individu melakukan perundungan-siber. Hasil ini mendukung temuan Brewer dan Kerslake (2015) yang pada penelitiannya menggunakan Toronto Empathy Questionnaire juga menemukan bahwa empati menjadi prediktor bagi perundung-siber. Hasil sebaliknya diperlihatkan dari analisis terhadap empati afektif yang tidak berkontribusi terhadap perundungan-siber ini.

Sebagaimana juga ditemukan dalam penelitian Suparli dan Ramdhani, semua dimensi emosi moral berkontribusi terhadap kecenderungan perundungansiber. Penelitian ini menemukan bahwa rasa bersalah merupakan emosi moral yang paling besar perannya terhadap perundungan-siber diikuti oleh malu, bangga hubristic dan bangga autentik. Walaupun tidak diungkap secara rinci mengenai yang mana yang lebih dahulu muncul, apakah emosi moral atau perilaku perundungan-siber namun analisis terhadap data yang diperoleh memperlihatkan bahwa rasa bersalah berpengaruh positif sehingga semakin tinggi rasa bersalah dari seorang individu maka semakin tinggi pula kecenderungan melakukan perundungan-siber. Temuan ini agak berbeda dengan kajian Farnworth, Drescher, Nieuwsma, dan Walser (2014) bahwa rasa bersalah ini sesungguhnya berpotensi mendorong individu untuk lebih empati dan tumbuhnya keinginan untuk terlibat dalam kegiatan memperbaiki kehidupan sosialnya.

Pengaruh sebaliknya diperlihatkan oleh emosi malu dan bangga, baik hubristic maupun autentik. Malu memberikan peran signifikan, walaupun tidak sekuat peran rasa bersalah, terhadap perundungan-siber. Hasil ini tidak sesuai dengan pendapat Tangney dan Dearing (2002) yang mengatakan bahwa malu mengandung potensi mendorong individu untuk marah, melakukan tindak agresif, bahkan penyalah gunaan obat-obatan. Studi ini memperlihatkan bahwa semakin tinggi emosi malu yang dirasakan oleh individu maka kecenderungannya melakukan perundungan-siber semakin rendah.

Rasa bangga di dalam konsep emosi moral masuk ke dalam kategori emosi moral positif, dibagi ke dalam dua macam yaitu bangga hubristic dan bangga autentik. Walaupun kedua konsep ini berbeda dalam hal orientasinya, bangga hubristic cenderung memperlihatkan kebanggaan kepada orang lain sedangkan bangga autentik lebih menekankan kepada rasa senang atas prestasi yang sudah dicapai atas kerja kerasnya, keduanya 
secara signifikan berpengaruh negatif terhadap perundungan-siber. Semakin tinggi rasa bangga, baik hubristic maupun autentik, yang dirasakan individu maka semakin kecil peluangnya melakukan perundungan-siber. Sejalan dengan temuan sebelumnya bahwa rasa bangga yang merupakan emosi moral positif berperan menurunkan perundungan-siber.

Tangney, et al. (2007) menyatakan bahwa emosi moral memediasi antara standar dengan perilaku moral. Dalam kehidupan sehari-hari standar moral yang berlaku umum di dalam masyarakat mengatakan bahwa perundungan termasuk ke dalam kategori perilaku moral yang tidak dapat diterima masyarakat. Apabila dalam perundungan tradisional terdapat kesenjangan antara dua atau lebih pihak sehingga pihak yang lebih mempunyai power merundung pihak lain yang kurang mempunyai power, tidak demikian halnya dengan perundungansiber dimana pelaku dan korban tidak selalu berbeda bahkan perundungan-siber dapat terjadi antara pihak yang tidak saling mengenal.

Teknologi telah mengubah cara kerja manusia. Pola hubungan atau kegiatan bersosialisasi tidak harus dilakukan pada saat dua pihak bertatap muka. Bahkan sosialisasi dapat terjadi antar pihak-pihak yang tidak begitu saling mengenal. Perubahan ini tentu saja membawa dampak kepada berubahnya pola pikir manusia (Turkle, 2005). Sebagaimana Suller $(1996 ;$ 2004) pernah mengemukakan bahwa pada saat berinteraksi melalui Internet individu merasa tidak ada orang yang mengenalinya (dissociative anonymity) dan tidak ada orang yang melihat (invisibility). Kondisi ini dapat mendorong individu menampilkan dirinya sebagai orang lain yang sama sekali berbeda dengan dirinya sehari-hari (Turkle, 2005).
Perasaan bersalah merupakan emosi moral negatif yang berfokus kepada internal individu. Perasaan ini muncul pada diri invidu setelah melakukan perbuatan tertentu yang dipersepsinya di bawah standar yang ia yakini, melanggar aturan yang berlaku, dan tidak sesuai dengan tujuan ideal perilaku yang diinginkan individu. Pada saat mengalami perasaan menyesal karena telah melakukan perilaku yang tidak diinginkan ini, individu menjadi lemah (Tangney \& Tracy, 2011). Di lain pihak pada saat berada di dalam kondisi ini, salah satu pelarian yang dapat dilakukan oleh individu di era teknologi informasi ini adalah beraktivitas dengan internet.

Dalam perspektif cyberpsychology, Suller (1996) mengemukakan bahwa lingkungan internet yang memberi efek tanpa hambatan (moral) karena pengguna tidak melihat siapa saja yang melihat dia, sebaliknya pengguna lain juga tidak melihat siapa dirinya (online dis-inhibition effect) memberi peluang lebih besar kepada penggunanya untuk bertindak sesuai dengan yang diinginkan tanpa harus mempertimbangkan aspek moral yang berlaku (dissociative imagination), beraktivitas di internet dianggap sekedar permainan saja.

Studi ini juga memperlihatkan bahwa emosi malu secara signifikan memainkan peran negatif terhadap kecenderungan melakukan perundungan-siber. Semakin merasa malu maka semakin kuat keinginan individu menarik diri, menyembunyikan diri dari dunia nyata, bahkan pada beberapa kasus malu yang dialami kaum veteran perang terdapat ide bunuh diri (Farnsworth, et al., 2014). Dengan kata lain, malu mendorong individu menarik diri dari kehidupan sosial sehingga terjauh dari kecenderungan melakukan perundungan-siber. Hasil studi ini tidak mendu- 
kung hipotesis yang diajukan karena nampaknya makna malu sebagaimana dikemukakan oleh Fessler (1999) antar budaya perlu dicermati kembali. Sebaliknya, Farnsworth, et al. (2014) mencantumkan bahwa individu yang merasa malu seakan kehilangan harga dirinya dan terlalu fokus kepada hal-hal negatif pada dirinya, ketidaknyamanan emosional yang dialaminya sehingga ia akan menarik diri dari kehidupan sosial dan kurang dapat berempati kepada orang lain bahkan terlibat dalam penyalahgunaan obat, mudah marah, dan agresif.

Hipotesis yang menyatakan bahwa kedua emosi moral yang positif, bangga hubristic maupun bangga autentik, memainkan peran penting untuk mengurangi kecenderungan perilaku perundungansiber secara signifikan terbukti. Semakin tinggi emosi bangga yang dialami individu makin kecil peluang melakukan perundungan-siber. Kedua emosi moral terkait rasa bangga ini memberikan masukan positif tentang diri sendiri, sebagai seorang yang berperilaku baik, kompeten, dan bijak. Penelitian yang dilakukan Farnsworth, et al. (2014) juga menemukan bahwa emosi moral positif ini berperan dalam menenangkan hati dan menyembuhkan rasa sedih dan sakit hati yang dialami selama peperangan. Dengan demikian, walaupun dimunculkan oleh sebab yang berbeda, emosi moral bangga merupakan variabel penting untuk melemahkan kecenderungan perilaku perundungan-siber.

Bila ditilik lebih lanjut peran emosi moral terhadap hubungan antara empati kognitif dan perundungan-siber nampaknya menjadi amat jelas bahwa hanya rasa bersalah yang merupakan moderator bagi hubungan antara empati dan perundungan-siber. Dimensi emosi moral lainnya memberikan sumbangan lebih besar ketika bersama-sama dengan empati memengaruhi perundungan-siber. Rasa bersalah yang lebih berfokus kepada evaluasi negatif individu atas perilaku spesifik yang pernah dilakukan individu menimbulkan tekanan dan rasa menyesal atas perilaku yang dipersepsi sebagai pelanggaran (Tangney, Stuewig, \& Mashek, 2007). Rasa bersalah ini agak berbeda dengan malu, yang lebih fokus kepada diri secara keseluruhan, sehingga rasa bersalah lebih mendekati aksi atau perilaku spesifik dibandingkan dengan malu yang berkaitan dengan diri (self). Pada saat seorang individu merasa terganggu karena berhadapan dengan stimulus yang diakses melalui teknologi internet, berbagai tekanan, rasa sesal, dan perasaan tidak nyaman yang dialaminya dapat mendorongnya berada pada situasi disosiasi, baik anonymity maupun imagination, yang mengarah kepada perundungan-siber.

\section{Kesimpulan}

Beberapa temuan penelitian ini mengarah kepada kesimpulan bahwa perundungan-siber lebih banyak dilakukan pada laki-laki. Temuan yang mengejutkan peneliti adalah korelasi yang positif antara empati kognitif dengan perundungan-siber, artinya semakin tinggi pemahaman terhadap perasaan orang lain maka akan semakin tinggi kecenderungan melakukan perundungan-siber. Korelasi antara empati kognitif dengan perundungan-siber ini semakin kuat pada individu yang memiliki rasa bersalah. Hasi penelitian ini mendorong penelitian selanjutnya untuk mengkaji saling hubungan antara variabel-variabel tersebut. 


\section{Daftar Pustaka}

Adler, R. B., \& Proctor, R. F. (2007). Looking out/looking in. Boston: Thomson/ Wadsworth

American Psychiatric Association. (2013). DSM 5. American Psychiatric Association.

Batson, C. D., Eklund, J. H., Chermok, V. L., Hoyt, J. L., \& Ortiz, B. G. (2007). An additional antecedent of empathic concern: Valuing the welfare of the person in need. Journal of Personality And Social Psychology, 93(1), 65. http://dx.doi.org/10.1037/0022-3514.93. 1.65

Berne, S., Frisén., A., Schultze-Krumbholz, A., Scheithauer, H., Naruskov, K., P. Luik, K., Katzer, C., Erentaite, R., \& Zukauskiene, R. (2013). Cyberbullying assessment instruments: A systematic review. Aggression and Violent Behavior, 18(2), 320-334. http://dx.doi.org/ 10.1016/j.avb.2012.11.022

Blair, R. J. R. (2005). Responding to the emotions of others: dissociating forms of empathy through the study of typical and psychiatric populations. Consciousness and cognition, 14(4), 698718. http://dx.doi.org/ 10.1016/ j.concog.2005.06.004

Blasi, A. (1999). Emotions and moral motivation. Journal for the Theory of Social Behaviour, 29(1), 1-19. http://dx.doi.org/ 10.1111/14685914.00088

Brewer, G., \& Kerslake, J. (2015). Cyberbullying, self-esteem, empathy and loneliness. Computers in Human Behavior, 48, 255-260. http://dx.doi.org/ 10.1016/j.chb.2015.01.073

Brislin, R. W. (1970). Back-translation for cross-cultural research. Journal of crosscultural psychology, 1(3), 185-216. http://dx.doi.org/10.1177/135910457000 100301

Brown, J. D. (2010). High self-esteem buffers negative feedback: Once more with feeling. Cognition and Emotion, 24(8), 1389-1404. http://dx.doi.org/ 10.1080/02699930903504405

Casey, V. (2014). Positive moral emotions and moral identity development: The difference between authentic and hubristic pride. Dissertation: Wilfrid Laurier University

Damanik, F. V., Widodo, M. K. D. N., Sutandi, M., Mayawati, E. H., \& Widyatmoko, C. S. (2013). Shame mediates attachment and submissive behavior in adolescent. In $\mathrm{H}$. Purba et al (editor), Psychology in changing global context: proceeding of the international conference on psychology in health, educational, social, and organizational settings (pages 612-617). Surabaya: Faculty of Psychology, Airlangga University.

Davis, M. H. (1980). A multidimensional approach to individual differences in empathy. JSAS Catalog of Selected Documents in Psychology, 10(85).

Davis, M. H. (1983). Measuring individual differences in empathy: Evidence for multidimensional approach. Journal of Personality and Social Psychology, 44, 113-126. http://dx.doi.org/10.1037/ 0022-3514.44.1.113

Decety, J., \& Jackson, P. L. (2006). A socialneuroscience perspective on empathy. Current directions in psychological science, 15(2), 54-58. http://dx.doi.org/ 10.1111/j.0963-7214.2006.00406.x

Del Rey, R., Lazuras, L., Casas, J. A., Barkoukis, V., Ortega-Ruiz, R., \& Tsorbatzoudis, H. (2016). Does empathy predict (cyber) bullying perpetration, and how do age, gender 
and nationality affect this relationship?. Learning and Individual Differences, 45, 275-281. http://dx.doi.org/ 10.1016/j.lindif.2015.11.021

Eisenberg, N., \& Fabes, R. A. (1990). Empathy: Conceptualization, measurement, and relation to prosocial behavior. Motivation and Emotion, 14(2), 131-149. http://dx.doi.org/ 10.1007/BF00991640

Endresen, I. M., \& Olweus, D. (2001). Selfreported empathy in Norwegian adolescents: Sex differences, age trends, and relationship to bullying. In A. C. Bohart, C. Arthur, \& D. J. Stipek (Eds.), Constructive and destructive behavior: Implications for family, school, and society (pp. 147-165). Washington, DC: American Psychological Association.

Farnsworth, J. K., Drescher, K. D., Nieuwsma, J. A., Walser, R. B., \& Currier, J. M. (2014). The role of moral emotions in military trauma: Implications for the study and treatment of moral injury. Review of General Psychology, 18(4), 249- 262. http://dx.doi.org/ 10.1037/gpr0000018

Fessler, D. M. T. (1999). Toward an understanding of the universality of second order emotions. A. Hinton (Ed.). Beyond nature or nurture: Biocultural approaches to the emotions, 75-116, New York: Cambridge U. Press.

Haidt, J. (2003). The moral emotions. R. J. Davidson, K. R. Scherer, \& H. H. Goldsmith (Eds.) Handbook of affective sciences, 11, 852-870, Oxford: Oxford University Press.

Hemmerdinger, J. M., Stoddart, S. D., \& Lilford, R. J. (2007). A systematic review of tests of empathy in medicine. BMC medical education, 7(1), 1.

Hoff, D. L., \& Mitchell, S. N. (2009). Cyberbullying: Causes, effects, and remedies. Journal of Educational Administration, 47(5), 652-665.

Hoffman, M. L. (2001). Empathy and moral development: Implications for caring and justice. Cambridge University Press

Holbrook, C., Piazza, J. R., \& Fessler, D. M. (2014). Further challenges to the "authentic"/"hubristic" model of pride: Conceptual clarifications and new evidence. Emotion, 14(1), 38 http:// psycnet.apa.org/http://dx.doi.org//10.1 037/a0035457

Kroll, J., \& Egan, E. (2004). Psychiatry, moral worry, and the moral emotions. Journal of Psychiatric Practice ${ }^{\circledR}, 10(6)$, 352-360.

Miklikowska, M., Duriez, B., \& Soenens, B. (2011). Family roots of empathyrelated characteristics: The role of perceived maternal and paternal need support in adolescence. Developmental Psychology, 47(5), 1342. http:// dx.doi.org/10.1037/a0024726

Patchin, J. W., \& Hinduja, S. (2006). Bullies move beyond the schoolyard a preliminary look at cyberbullying. Youth violence and juvenile justice, 4(2), 148-169. http://dx.doi.org/ 10.1177/1541204006286288

Perren, S., \& Gutzwiller-Helfenfinger, E. (2012). Cyberbullying and traditional bullying in adolescence: Differential roles of moral disengagement, moral emotions, and moral values. European Journal of Developmental Psychology, 9(2), 195-209. http://dx.doi.org/ .org/10.1080/17405629.2011.643168

Robinaugh, D. J., \& McNally, R. J. (2010). Autobiographical memory for shame or guilt provoking events: Association 
with psychological symptoms. Behaviour Research and Therapy, 48(7), 646652.

Spreng, R. N., McKinnon, M. C., Mar, R. A., \& Levine, B. (2009). The Toronto Empathy Questionnaire: Scale development and initial validation of a factor-analytic solution to multiple empathy measures. Journal of personality assessment, 91(1), 62-71. http://dx.doi.org/10.1080/002238908024 84381

Steffgen, G., König, A., Pfetsch, J., \& Melzer, A. (2011). Are cyberbullies less empathic? Adolescents' cyberbullying behavior and empathic responssiveness. Cyberpsychology, Behavior, and Social Networking, 14(11), 643-648. http://dx.doi.org/:10.1089/cyber.2010.0 445

Suller, J. (1996). The psychology of cyberspace. Department of psychology, Science and Technology Center: Rider University.

Suller, J. (2004). The online disinhibition effect. Cyber Psychology and Behavior, 7(3), 321-326. http://dx.doi.org/ 10.1089/1094931041291295

Suparli, A. S., \& Ramdhani, N. (2015). Does Moral Emotion Plays Role in Cyber-bullying?. Procedia-Social and Behavioral Sciences, 165, 202-207. http://dx.doi.org/10.1016/j.sbspro.2014. 12.623

Tangney, J. P., \& Dearing, R. L. (2002). Shame and guilt. New York: Guilford Press

Tangney J. P., Malouf, E., Stuewig, J., \& Mashek, D. (2011). Emotions and morality: You don't have to feel really bad to be good. In Michael W. Eysenck, Magorzata Fajkowska, \& Tomasz Maruszewski (Eds.), Perso- nality, Cognition, and Emotion, (141154). New York: Eliot Werner Publications.

Tangney, J. P., Stuewig, J., \& Hafez, L. (2011). Shame, guilt, and remorse: Implications for offenders populations. The Journal of Forensic Psychiatry and Psychology, 22(5), 706-723. http:// dx.doi.org/10.1080/14789949.2011.6175 41

Tangney, J. P., Stuewig, J., \& Mashek, D. J. (2007). Moral emotions and moral behavior. Annual Review of Psychology, 58(1), 345-372. http://dx.doi.org/ 10.1146/annurev.psych.56.091103.0701 45

Tangney, J. P., \& Tracy, J. (2011). Selfconscious emotions. In Mark E. Leary \& June P. Tangney (Eds.). Handbook of self and identity (446-480). New York: Guilford Press.

Tracy, J. L., Shariff, A. F., \& Cheng, J. T. (2010). A naturalist's view of pride. Emotion Review, 2(2), 163-177. http://dx.doi.org/10.1177/175407390935 4627.

Tracy, J. L., Robins, R. W., \& Tangney, J. P. (Eds.). (2007). The self-conscious emotions: Theory and research. New York: Guilford Press.

Turkle, S. (2005). The second self: Computers and the human spirit. MIT Press

Weiner, B. (1985). An attributional theory of achievement motivation and emotion. Psychological review, 92(4), 548. http://dx.doi.org/ 10.1037/0033295X.92.4.548

Wong-Lo, M., \& Bullock, L. M. (2014). Digital metamorphosis: Examination of the bystander culture in cyberbullying. Aggression and violent behavior, 19(4), 418-422. http:// dx.doi.org/10.1016/j.avb.2014.06.007 